After being welcomed by Dr. F. W. G. White, Chairman of the Commonwealth Scientific and Industrial Research Organization, the Governor-General began by reading a message from H.R.H. The Duke of Edinburgh:

"The development of radio astronomy has been one of the great events of modern Science, and the scientists of C.S.I.R.O. have played a leading part in this important work. Their studies of the Sun and the exploration of extraterrestrial space to the remotest parts of the universe have gained the admiration of astronomers everywhere and have brought great credit to Australia.

"To-day the radio astronomers of Australia are to be rewarded by the inauguration of a magnificent radio telescope which will enable them to penetrate still further the secrets of the cosmos. This occasion marks the culmination of much planning and hard work and I send you my best wishes for the success of your investigations with this new instrument."

His Excellency then discussed the way in which realization of this "Giant Radio Telescope" had come about as the result of a happy conjunction in Australia of several distinct, but all of them propitious, cireum. stances. "Thus conceived and encouraged, the enterprise has leapt forward at a pace which I found both admirable and refreshing." $\mathrm{He}$ closed in whimsical mood with a quatrain which "seemed to float into my mind from an extra-planetary source":

$$
\text { "Twinkle, twinkle radio star. }
$$

We can't see you : you're too far.

Now we hear from outer space

How you run your cosmic race."

The next speakers were Dr. The Hon. D. A. Cameron, the Minister-in-Charge of the Commonwealth Seientific and Industrial Research Organization, and The
Right Hon. Lord Casey, who was Minister-in-Charge of the Organization during the early critical stages of the project, and has continued his connexion with it as chairman of the Radio Astronomy Trust.

At this stage the Governor-General performed the commissioning ceremony, and a large Australian flag was broken out above the focus cabin, the highest point of the structure. Unfortunately, wind gusts of more than 50 m.p.h. interfered with a plan to tilt the dish down towards the assembled crowd. The area is normally very calm, which in fact was one of the ressons for its choice; but on this ceremonial occasion the weather was unkind, with wind-speeds at their highest level for several years.

Dr. Bowen closed the proceedings by outlining some of the plans for the future use of the instrument. A number of important observational programmes are ready to start as soon as the present period of extensive tests is completed. These include work on the identification of extragalactic sources, and studies of galactic structure, the Magellanic Clouds, bright hydrogen regions, and the planet Jupiter.

The new instrument will make a powerful addition to the facilities available to the Australian radio astronomers; but it is also a notable gain for the astronomical world at large. To quote Dr. Bowen's concluding remarks: "When the first urgent tasks of the next few months have been performed, it will be thrown open to astronomers from every part of the world with worthwhile problems to attack. We pledge ourselves to work in close collaboration with our fellow scientists from any country and will make this Observatory a rallying point for equipment and information, for techniques and intellects which, together, will lead to further great advances in the science of astronomy".

\title{
OBITUARIES
}

\section{Prof. Robert Boutflour, C.B.E.}

Prof. Robert Boutrlour, who had resigned as principal of the Royal Agricultural College in 1958, died on October 27 in Cirencester at the age of seventy-one. He was educated at Barnard Castle School and Armstrong College-now King's College, Newcastle upon Tyne.

Boutflour's first appointment was lecturer in agriculture with the Iancashire County Council; this was followed by a similar post in the University of Leods, and in 1921 he was appointed agricultural officer for the County of Lindsey. In 1922 he was made chief agricultural officer to the Wiltshire County Council, where he remained until 1926, when he was appointed the first and, last national director of dairy husbandry.

He is best known for his work on the breeding and management of dairy cattle. This he started in Wiltshire, where it was realized that he was a man of sound progressive ideas, and in fact, many years ahead of his time, which is now proved inasmuch as his ideas are now accepted in general practice. His fame extended abroad as well as at home, and he is well known to many farmers of the territories he visited in the United States, Canada, Kenya and Australia.

While national director of dairy husbandry, he was attached to the Harper Adams Agricultural College, where he established his famous Friesian herd of dairy cattle. This enterprise proved to be an outstanding success and enabled him to put into practice those points of management that he had so strenuously advocated to farmers throughout the United Kingdom.

Boutflour was an impressive author and wrote many works on farm management in general, and the subject of dairy cattle in particular. While his success as a scientist was largely due to his keen powers of observation, coupled with patient and inspired reasoning, his ability to impress audiences or individuals was the result of his enthusiasm, alert mind and logical arguments coupled with a quick wit. In character and speech he was always most forthright, but his caustic remarks were usually offset with a characteristic twinkle in his eyes.

His appointment as principal of the Royal Agricultural College in 1931 gave him the necessary scope for his ability in organization and administration. and particularly to associate with young people, to whom he was always willing to give advice and encouragement. When he retired from the principalship in 1958 he had the satisfaction of knowing that during his term of office he had increased the number of students from 48 to more than 450 .

During the Second World War, as executive officer for food production in Gloucestershire, he adopted many revolutionary methods to increase the output of food. One of his most daring ventures was to 
plough up the Slimbridge pastures adjoining the River Severn, which for centuries had been the habitat of wild geese. His critics said that with this terrific fertility no cereal crop would 'stand,' but once again he proved them wrong. He was created C.B.E. in 1952, and in 1955 he received the Sir Thomas Baxter Prize and Gold Medal for outstanding work in dairy husbandry.

However, it is by his personal character that so many will remember him, and among his personal characteristics was a 'human' appreciation of his fellow men and the possession in a very large measure of that great virtue-tolerance. His wife, who survives him, was the greatest help to him throughout his varied career, by her companionship and understanding. The passing of this colourful character has created a void which will be difficult, if not impossible, to fill, and to the older generation who knew him-and there are so many-Bob Boutflour will always remain in their memory with affection as a generous, likeable and very 'human' person of outstanding ability; while the younger generation will reap the benefit of his scientific work, and the valuable contribution he made to British and, in fact, world agriculture.

W. T. Price

\section{Dr. A. E. Western}

Alfred Enward Western, who died on October 11 at the age of eighty-eight, was one of the few who have been able to carry on mathematical research while fully engaged in another profession: in his case, that of a solicitor. He was educated at Marlborough and at Trinity College, Cambridge, which he entered. with an open scholarship in 1892. He was seventh Wrangler in the Mathematical Tripos in 1895; the year in which Bromwich was Senior Wrangler and E. T. Whittaker second Wrangler.
Dr. Western published several memoirs on the theory of algebraic numbers, and one on the theory of groups, during the years 1898-1911, and showeri himself to be thoroughly at home in a subject which was then little cultivated in Britain. His standing as a mathematician was recognized by the award of the degree of Sc.D. by the University of Cambridge in 1910. He gradually became more interested in ques. tions of numerical computation, and published several notes giving the numerical evidence which he had found for various conjectured formulæ of Hardy and Littlewood relating to the distribution of primes. to the occurrence of primes of the form $n^{2}+1$, and to Waring's problem.

During the last years of his life he was engaged (jointly with Dr. J. C. P. Miller) in completing a table projected by the late Lieut.-Colonel A. J. C. Cunningham, with whom he had formerly collaborated. This table, which is essentially a continuation of Jacobi's Canon Arithmeticus, is shortly to be published with the help of a bequest made by Cunningham to the London Mathematical Society for the purpose.

Dr. Western was closely associated with the London Mathematical Society over a long period. and rendered great service to it. $\mathrm{He}$ became a member of the Council in 1900, and treasurer in 1913 in succession to Sir Joseph Larmor. He retired from this office in 1950 , and many members will recall the delightful speech he made at a dinner held at that time.

As a solicitor, Dr. Western was a pioneer in initiating 'legal aid', and it was largely from his work that the legal aid scheme used in courts in Britain developed.

He will be remembered by many as a man of great kindliness and of transparent sincerity and honesty of purpose.

\section{NEWS and VIEWS}

\section{Geology at Trinity College, Dublin:}

Dr. R. G. S. Hudson, F.R.S.

The chair of geology and mineralogy at Trinity College, Dublin, vacated by Prof. W. D. Gill on his appointment to the chair of oil technology at the Imperial College of Science and Technology, Iondon (see Nature, 191, 651; 1961), has been filled by the appointment of Dr. R. G. S. Hudson, Iveagh Research Fellow in geology at Trinity. Dr. Hudson, who studied geology at University College, London, under the late Prof. E. J. Garwood, joined the staff of the Geological Department at Leeds in 1922, became professor of geology in 1939 and during 1940-45 acted as consulting geologist to various companies engaged in the search for oil in Great Britain. During these years he published mainly on the Dinantian and Namurian of the north of England, demonstrating the rhythmic succession of the Yoredale Series, the stratigraphical relationship of the limestone of the Craven Reef Belt, the pre-Namurian age of the Mid-Craven Fault, and helped in mapping a large part of the Craven Lowlands. He also worked with W. S. Bisat on the goniatite faunas of the Namurian and, in particular, detailed the goniatite succession in the Alport Boring in Derbyshire. During 1946-58 he was a senior research geologist and paliontologist with the Iraq Petroleum Company, leading field exploration parties in Kurdistian, Iraq (1949, 1950) and in the Oman Mountains of Arabia (1951, 1952). and publishing on the stratigraphy and faunas of these areas. Much of the present knowledge of the Middle East Mesozoic faunas, in particular the stromatoporoids and bydrozoa, is due to his work. $\mathrm{He}$ has received the Foulerton Award of the Geologists' Association and the Wollaston Award and Murchison Medal of the Geological Society. He has also been president of the Yorkshire and the Liverpool Geological Societies and the Palæontological Association, and a vice-president of the Geological Society. In 1959 he was made an honorary member of the Société Belge de Géologie et Paléontologie. and in 1961 he was elected to the Royal Society.

\section{The British Nuclear Energy Society}

ON January 1, 1962, the British Nuclear Energy Society will be established in succession to the British Nuclear Energy Conference. The successful use of nuclear energy demands the application of many divisions of science and technology and a constant interchange of knowledge and experience between those trained primarily in these divisions. It was to provide a channel for this interchange that in 1955 